\title{
Preliminary photographs and improved positives: discovering the New York Public Library's Arctic Exploration album
}

\author{
Elena Basso ${ }^{1 *} \mathbb{D}$, Federica Pozzi ${ }^{1 *}$, Jessica Keister ${ }^{2,3}$ and Elizabeth Cronin ${ }^{4}$
}

\begin{abstract}
In the late 19th and early 20th centuries, original photographs were sent to publishers so that they could be reproduced in print. The photographs often needed to be reworked with overpainting and masking, and such modifications were especially necessary for low-contrast photographs to be reproduced as a letterpress halftone. As altered objects, many of these marked-up photographs were simply discarded after use. An album at The New York Public Library, however, contains 157 such photographs, all relating to the Jackson-Harmsworth expedition to Franz Josef Land, from 1894 to 1897. Received as gifts from publishers, the photographs are heavily retouched with overpainting and masking, as well as drawn and collaged elements. The intense level of overpainting on many of the photographs, but not on others, raised questions about their production and alteration. Jackson's accounts attested to his practice of developing and printing photographs on site, testing different materials and techniques-including platinobromide and silver-gelatin papers - to overcome the harsh environmental conditions. In this context, sixteen photographs from the album were analyzed through a combination of non-invasive and micro-invasive techniques, including X-ray fluorescence (XRF) spectroscopy, fiber optics reflectance spectroscopy (FORS), Raman and Fourier-transform infrared (FTIR) spectroscopies, and scanning electron microscopy with energy-dispersive X-ray spectroscopy (SEM/ EDS). This analytical campaign aimed to evaluate the possible residual presence of silver halides in any of the preliminary and improved photographs. The detection of these compounds would be one of several factors supporting a hypothesis that some of the photographs in the album were indeed printed on site, in the Arctic, and, as a result, may have been impacted by the extreme environment. Additional goals of the study included the evaluation of the extent of retouching, providing a full characterization of the pigments and dyes used in overpainted prints, and comparing the results with contemporaneous photographic publications that indicate which coloring materials were available at the time. Further analyses shed light on the organic components present in the binders and photographic emulsions. This research has increased our knowledge of photographic processes undertaken in a hostile environment such as the Arctic, and shed light on the technical aspects of photographically illustrating books during the late 19th and early 20th centuries.
\end{abstract}

Keywords: Expeditionary photography, Photographs, Arctic expeditions, Late 19th and early 20th centuries, Silvergelatin paper, Silver halides, Retouching, Overpaint, Halftones

*Correspondence: elena.basso@metmuseum.org; federica. pozzi@metmuseum.org

${ }^{1}$ Department of Scientific Research, The Metropolitan Museum of Art, 1000 Fifth Avenue, New York, NY 10028, USA

Full list of author information is available at the end of the article

\section{Introduction}

Mid-19th-century polar expeditions relied on photography to record and document their journeys and the landscape of the far North. Thoroughly chronicled, these expeditions hoped to later disseminate their successes to an adventure-hungry public in books and lectures. 
Procuring quality photography in the Arctic, however, was quite difficult: it required finesse, patience, and a lot of trial and error. The earliest attempts to bring photography to a hostile environment of extreme weather were unsuccessful, and obtaining a satisfactory image was only half the problem. One of the many challenges of these expeditions was to make it back safely, which often meant abandoning precious scientific data and records. Daguerreotype equipment, for example, was included as part of Sir John Franklin's expedition to the Arctic in 1845 , but any exposed plates went down with the ships and did not survive the infamously tragic mission [1]. A few years later, in 1853, Amos Bonsall succeeded in making daguerreotypes during Elisha Kent Kane's Second Grinnell expedition, but they, too, had to be abandoned with the ship when it was determined that a land retreat was the only option [2].

Later 19th-century expeditions were often, though not always, better prepared. Technological advances in photographic equipment and processes also made it easier to photograph. For instance, cameras were more portable and the whole photographic process slightly more accessible to novices. The invention and use of the wet collodion process for making albumen silver prints seemed to coincide with more successful Arctic voyages [3]. Recognizing the importance of photographic documentation, Isaac Israel Hayes taught himself how to photograph, and brought back negatives that were then made into albumen silver print stereographs [2]. Shortly thereafter, in 1869, he accompanied the artist William Bradford and his two professional photographers Dunmore and Critcherson on their artistic journey to Greenland [4]. Their photographs, which Bradford published in Arctic Regions, are the best-known examples of 19th-century Arctic photography. Expensive to produce, Bradford's album contained 141 albumen silver prints that were pasted in by hand and interspersed throughout the printed text. The development and refinement of the halftone printing process in the mid-1880s, which reproduced photographs by transforming the continuous tonal gradations of a photograph into series of dots, made it easier and less expensive to include photography in books.

A photographic album in the Photography Collection of the New York Public Library (NYPL) titled Arctic Exploration provides rare insight into the halftone process, as well as demonstrating how onerous and complicated photographing, producing, and printing photographs from the Arctic was. The album is a hodgepodge of photographs from various Arctic expeditions spanning a 30-year period of exploration. Received as gifts from publishers, the Library assembled the varied prints into one thematic volume in the early 1920s. The album, measuring $30.8 \times 25.4 \times 5.7 \mathrm{~cm}\left(12^{1} / 8 \times 10 \times 2 \frac{1}{4}\right.$ inches), has a brown starched buckram exterior with thick boards and heavy grade book cloth that were typical for the time. Most of the photographs placed within the album were "improved" and heavily reworked with overpainting and masking, as well as drawn and collaged elements. These altered prints were not intended as completed artistic works, but as tools for photomechanical reproduction. They were printed as letterpress halftones and ultimately appeared in Frederick George Jackson's 1899 book $A$ Thousand Days in the Arctic, an account of his 1894-1897 expedition to Franz Josef Land.

Most technical studies of 19th-century photographic media to date focus on daguerreotypes and their degradation [5-20]. Attention to other 19th-century photographic processes, however, has been rising thanks to the availability of cutting-edge methods of non-invasive instrumental analysis, although these studies mostly aim to characterize photographic supports, materials, and techniques used by a single photographer or for a specific photographic category [21-30]. The materials used in developing and printing processes during the late 19th and early 20th centuries have been largely investigated, but the results of photographic processes undertaken in the frigid environment of the Arctic have not been studied from a scientific standpoint, nor have the methods for creating halftone reproductions been examined.

In this study, the NYPL's Arctic Exploration album was subjected to an in-depth analytical campaign aiming to evaluate the possible presence of residual silver halides in any of the preliminary and improved photographs. The detection of these compounds would be one of several factors supporting a hypothesis that some of the photographs in the album were indeed printed on site, in the Arctic, and, as a result, may have been impacted by the extreme environment. Moreover, the extensive retouching present on the improved positives afforded an opportunity to provide a full characterization of the pigments and dyes used in overpainted prints, and to compare these results with data on coloring materials from contemporaneous photographic publications in the research collection of the Library's Wallach Division of Art, Prints and Photographs. Additional analyses aimed to investigate the organic components present in the binders and photographic emulsions. This study increases the current knowledge of the technical aspects of photomechanically illustrated books during the late 19th and early 20th centuries. Most importantly, since overpainted and retouched photographs were often discarded after their use, this research on the Arctic Exploration album offers a rare glimpse into the practice and method of producing halftones. 


\section{Experimental}

The present study, focusing on sixteen photographs from the Arctic Exploration album (Table 1), entailed a first campaign of in-situ, non-invasive investigations carried out at the NYPL Wallach Division of Art, Prints and Photographs' Study Room. This work was followed by removal of four samples and micro-invasive analysis using an array of benchtop instruments in the Department of Scientific Research (DSR) of The Metropolitan Museum of Art (The Met). Portable X-ray fluorescence (pXRF) spectroscopy was initially employed to investigate the possible presence of residual halides in any of the photographs and to gather information on the elemental composition of the applied colors. Subsequently, fiber optics reflectance spectroscopy (FORS) and handheld Raman spectroscopy aimed to provide a more detailed characterization of the color palette used for retouching. In order to better understand the album, and in preparation for micro-invasive analysis and conservation treatment, the photographs were carefully inspected under normal viewing conditions, by means of a binocular microscope, and with both long-wave $(365 \mathrm{~nm})$ and short-wave $(254 \mathrm{~nm})$ ultraviolet (UV) light sources. To minimize potential damage, a limited number of microscopic paint samples was removed from retouched areas of photographs $18,31,48$, and 56 (Table 1 ) using a surgical scalpel blade. These samples were then analyzed by micro-Raman and Fourier-transform infrared (FTIR) spectroscopies, as well as scanning electron microscopy with energy-dispersive X-ray spectroscopy (SEM/EDS), to identify pigments and dyes in more detail, and to investigate the organic components present in the binders and photographic emulsions. Measurement areas were carefully chosen and, unless otherwise specified, for each technique several spots were analyzed to ensure reproducibility of the results. Experimental conditions for the analytical techniques employed are reported in the following section.

$p X R F$ Analysis was performed using an Elio XGLab energy-dispersive portable XRF spectrometer, with a high-resolution large-area silicon drift detector (SDD)

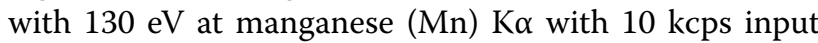
photon rate (high resolution mode), and $170 \mathrm{eV}$ at $\mathrm{Mn}$ K $\alpha$ with $200 \mathrm{kcps}$ input photon rate (fast mode). The system is equipped with changeable filters, and a rhodium (Rh) transmission target with $50-\mathrm{kV}$ maximum voltage and 4-W maximum power. The size of the spot analyzed was $1 \mathrm{~mm}$. Parameters employed for the analysis were as follows: $50-\mathrm{kV}$ voltage, $80-\mu \mathrm{A}$ current, 300 -s acquisition time, and no filter for printed areas and the photographic

Table 1 List of photographs analyzed, with indication of their title, category, and samples removed for micro-invasive analysis of the retouching paint

\begin{tabular}{|c|c|c|c|}
\hline Photograph & Title & Category $^{a}$ & Samples \\
\hline 11 & $\begin{array}{l}\text { The Scene Outside the Hut is Desolate and Dreary in the } \\
\text { Extreme }\end{array}$ & Improved (retouching) & \\
\hline 18 & $\begin{array}{l}\text { The Fantastically Irregular Surface of the Great Ice-floes, } \\
\text { Cape Flora from the Floes by Moonlight }\end{array}$ & Improved (retouching) & $\begin{array}{l}\text { S1) Scraping of blue paint from snowbanks on proper } \\
\text { left side of bottom edge }\end{array}$ \\
\hline 23 & Sea Ice Crushed Up by Pressure on the Shore at Cape Flora & Improved (retouching) & \\
\hline 31 & Walrus Asleep on a Piece of Drifting Ice & Improved (retouching) & $\begin{array}{l}\text { S2) Scraping of purple-blue paint from sky on top edge } \\
\text { at proper left of center }\end{array}$ \\
\hline 32 & Our Start North, March, 1895 & Improved (retouching) & \\
\hline 39 & A Samoyad Village Beauty & Improved (retouching) & \\
\hline 48 & A Camp & Improved (retouching) & $\begin{array}{l}\text { S3) Scraping of purple paint from sky on upper portion } \\
\text { of proper right edge }\end{array}$ \\
\hline 56 & Our Coal-sacks, by Moonlight & Improved (retouching) & $\begin{array}{l}\text { S4) Scraping of purple paint from sky on upper portion } \\
\text { of proper right edge }\end{array}$ \\
\hline 93 & Brownie, Poor Beast, Lay Down Several Times & Preliminary & \\
\hline 94 & In Difficulties & Preliminary & \\
\hline 97 & Dog-team Under Way with Sail & Preliminary & \\
\hline 108 & $\begin{array}{l}\text { I Went Up to Within Eight Yards of Him and Killed Him } \\
\text { with One Shot }\end{array}$ & Improved (retouching) & \\
\hline 118 & $\begin{array}{l}\text { Taking Observations for Position at Our Second Camp on } \\
\text { Cape Grant }\end{array}$ & Improved (retouching) & \\
\hline 171 & In Difficulties & Improved (retouching) & \\
\hline 172 & A Rest on the March & Improved (retouching) & \\
\hline 173 & Dog-team Under Way with Sail & Improved (retouching) & \\
\hline
\end{tabular}

a Following categories described by Newman in 1874 [31]. 
paper; $50-\mathrm{kV}$ voltage, $40-\mu \mathrm{A}$ current, $90-\mathrm{s}$ acquisition time, and no filter for regions of retouching paint. Specific settings for each analysis have been reported in the net counts table in Additional file 1: Table S1. Empty areas of the album page secondary supports were analyzed as a reference in each case to allow for a correct attribution of the elements detected. For each color or element selected for analysis, three measurements were collected. Qualitative and semi-quantitative comparisons among areas with different image densities, indicated as $\mathrm{D}_{\max }$ (maximum density), $\mathrm{D}_{\text {mid }}$ (medium density), and $\mathrm{D}_{\text {min }}$ (minimum density), assisted in differentiating between elements that are associated with the image material and those that are present in the paper support or artist's mount.

FORS Analysis was performed using an Ocean Optics (USB2000+UV/Vis) spectrometer equipped with a linear silicon charge-coupled device (CCD) array. In this system, the area selected for analysis is illuminated through a halogen lamp coupled with fiber optics. Reflected light is collected by a co-axial fiber and driven to the spectrometer. Analysis was carried out by positioning the tip of the fiber optics at approximately $1-2 \mathrm{~mm}$ from the photograph's surface, resulting in a spot size of approximately $0.2 \mathrm{~mm}$. Reflectance (R) data were converted to apparent absorption using the Kubelka-Munk algorithm; in fact, it is more reliable to look for absorption features, whose wavelength positions are known to remain more constant [32].

Raman Non-invasive analysis was conducted using a handheld Bruker Bravo Raman spectrometer equipped with a CCD detector. Two lasers emitting light at 785 and $852 \mathrm{~nm}$ (Duo LASER ${ }^{\mathrm{TM}}$ ) were used as the excitation sources, and spectral resolution was $10-12 \mathrm{~cm}^{-1}$ [33]. The output laser power was $\approx 50 \mathrm{~mW}$ for both lasers, while the number of scans and integration time were set to 30 and $1000 \mathrm{~ms}$, respectively. Micro-invasive analysis of samples was performed using a benchtop Bruker Senterra Raman spectrometer equipped with an Olympus $50 \times$ long working distance microscope objective and a CCD detector. A continuous wave diode laser, emitting light at $785 \mathrm{~nm}$, was employed as the excitation source, and two holographic gratings (1800 and 1200 rulings/ $\mathrm{mm}$ ) provided a spectral resolution of $3-5 \mathrm{~cm}^{-1}$. The output laser power was kept below $10 \mathrm{~mW}$ to prevent damage from overheating, while the number of scans and integration time were adjusted according to the Raman response of each sample. In both cases, spectra were interpreted by comparison with published literature and library databases available at The Met's DSR.

FTIR Analysis was conducted in transmission mode with a Hyperion 3000 FTIR spectrometer equipped with a mercury cadmium telluride (MCT) detector. Each sample was crushed in a Spectra Tech diamond anvil cell and all the materials contained in it were analyzed as a bulk through a $15 \times$ objective. Spectra were collected in the $4000-600 \mathrm{~cm}^{-1}$ range, at a resolution of $4 \mathrm{~cm}^{-1}$, as the sum of 256 scans. Spectra were interpreted by comparison with published literature and library databases available at The Met's DSR.

$S E M / E D S$ Samples were mounted on an aluminum stub with carbon tape and analyzed with a FE-SEM Zeiss igma HD equipped with an Oxford Instrument $\mathrm{X}-\mathrm{MaxN} 80$ SDD. Back-scattered electron (BSE) imaging, as well as EDS elemental spot analysis and mapping, were performed in high vacuum with an accelerating voltage of $20 \mathrm{kV}$, on $12-\mathrm{nm}$ carbon-coated samples, at an $8.5-\mathrm{mm}$ working distance.

\section{Results and discussion}

The sixteen photographs documenting Jackson's Arctic expedition were divided into two categories, according to Newman's terminology [31]: "preliminary photographs" and "improved positives" (Table 1; Fig. 1). Preliminary photographs are small $(6.8-7 \times 9.4-10.1 \mathrm{~cm})$ and few in number. They are low-contrast photographs with warm purple image tonalities, printed on silver-gelatin printing-out papers. Improved positives reproduce the same images as the preliminary photographs, but are larger in size $(11.5 \times 16.7-18.1 \mathrm{~cm})$. Printed as exceptionally lowcontrast salt paper enlargements, most of the improved positives exhibit considerable overpainting. The remaining photographs in the album from Jackson's expedition are also improved positives, though they are printed on silver-gelatin printing-out papers. Likely created later, after the expedition returned to a more temperate climate, the silver-gelatin printing-out paper prints used were common and relatively inexpensive to produce and were thus ideal for "improving" [34].

Retouching was required for a low-contrast photograph to be successfully reproduced as a halftone, as photographs with higher contrast and a wider tonal range yielded better reproductions. Obtaining a high contrast image was a consistent, known problem in photographing the Arctic landscape, where a good dark room and daily developing were requirements for maintaining the quality of light [35]. John Dunmore, one of the photographers on the 1869 William Bradford expedition, complained: "My great trouble, while away, was reflected light. Everything worked flat, and I could not force the negative up-the stronger the bath the flatter the negative" [36]. Unless a photograph is captured under very specific lighting conditions, enabling such high contrasts, some degree of print retouching is usually required in order to reproduce a photograph as a halftone. A 1921 text explains the issue as follows: "The conditions under which 


\section{Preliminary photograph}
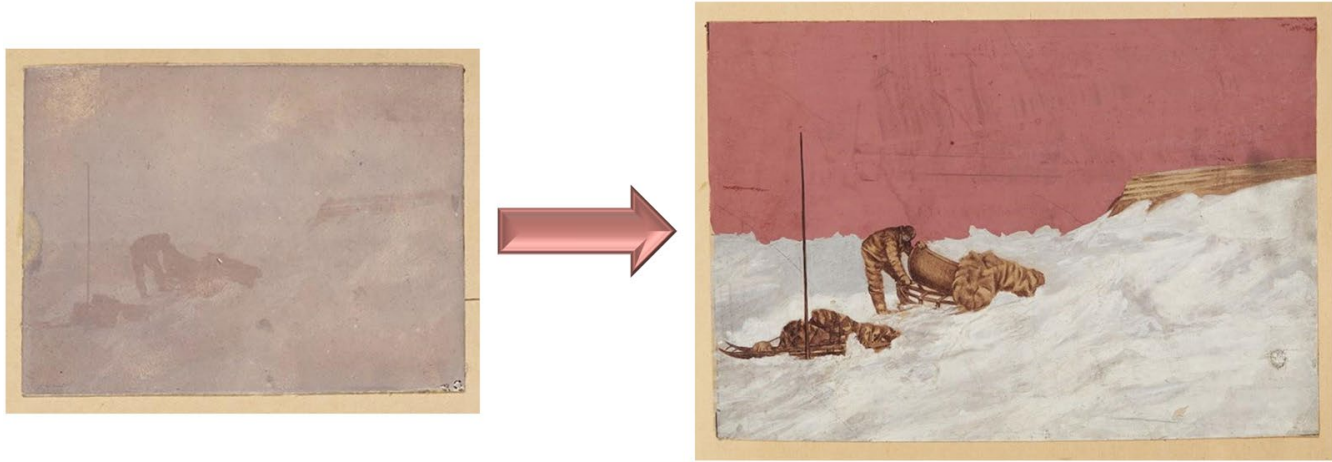

Improved positive
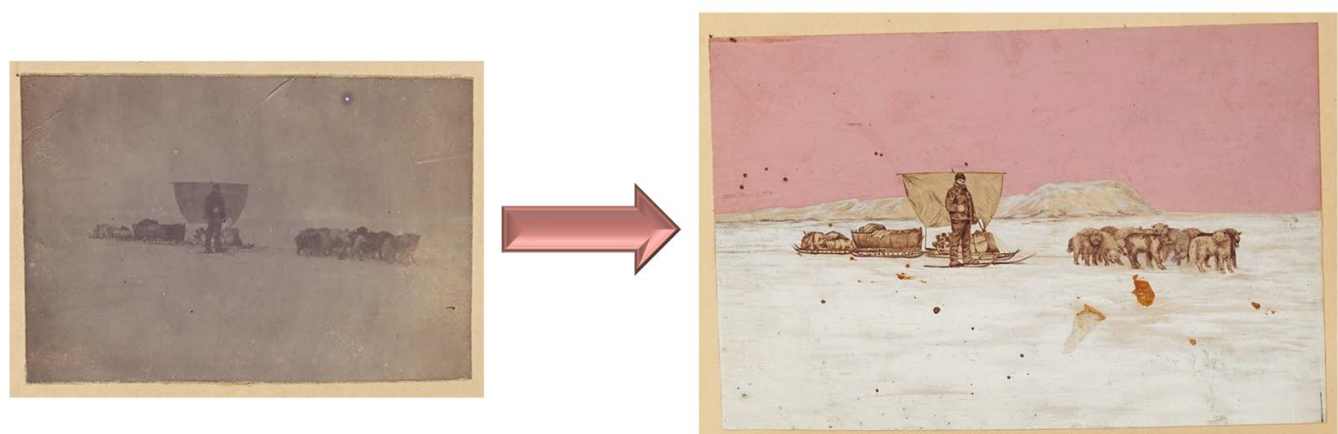

Fig. 1 Examples of preliminary photographs (left) and corresponding improved positives (right) from the Arctic Exploration album, 1890s-?, MFY + 96-4073, The New York Public Library. Photography by J. Keister. Top, from left to right: plate $94(7 \times 9.4 \mathrm{~cm})$; plate $171(11.6 \times 16.7 \mathrm{~cm})$. Bottom, from left to right: plate $97(6.8 \times 10.1 \mathrm{~cm})$; plate $173(11.8 \times 18.1 \mathrm{~cm})$

the average photographer must work make it impossible in most instances for him to get photographs that are up to the high standard required for the best halftone reproductions, and even though the photographs are made under the most favorable conditions some subjects will require retouching to give the reproductions the attention-getting qualities they should have" [37].

By the mid-1880s, the halftone printing process had been perfected and became an inexpensive solution to the challenge of mechanically reproducing a photograph [38]. The primary difficulty lay in converting the continuous tone and gradations of a photograph into a series of dots or lines. The object to be reproduced in halftone form was placed in front of a large process camera, and a halftone screen was put in direct contact with the negative or at a specific distance determined by the screen resolution. Made of intersecting lines on a transparent support, the halftone screen created evenly spaced apertures of equal size. The light passing through the screen broke the continuous tone of the original into a series of regularly spaced dots. This halftone negative was then exposed onto a metal plate sensitized with dichromated gelatin. Areas of gelatin exposed to light would harden, while unexposed regions would remain soft and watersoluble. After exposure, the plate was washed and etched, the hardened gelatin acting as a resist. The plate would then be proofed, mounted into the printing chase, and inked. Highlights were marked with tiny dots, using little ink, while shadows and other areas of high image density were marked with large dots, using high amounts of ink. Finally, the plate could be edited or modified as any ordinary etched plate.

\section{Preliminary photographs: printed in the Arctic?}

The tiny size and lackluster image quality of the selection of preliminary photographs investigated here suggest but show no visible indication as to whether or not they might have been processed on site. The severe cold and variable light conditions in the Arctic compelled photographers to repeatedly print their negatives and modify their technique accordingly to ensure legible exposures. As expedition photographer Rudolf Kersting explained: "No dust of any kind is in the atmosphere; it is pure, clear air. It is easy to make good pictures under these conditions, if you study your light. The great difficulty is near the seashore, where with ordinary plates or films, proper 
exposure is next to an impossibility" [35]. Jackson was certainly conscious of the current weather and light variations, and his expedition logs contain numerous references to negatives being developed almost daily [39]. While printing photographs was not among the activities pursued at the start of Jackson's expedition, a later supply ship that delivered various photographic papers enabled that prints could be made on site. The challenge of getting enough light to create a high-quality photographic image, however, was doubled in his attempts using mid-autumn Arctic sunlight, which often gave rise to low-contrast, minimal detail images. Originally, the authors thought that incomplete washing and poor print processing in the far North could have contributed to the muted and dark images, resulting in residual silver halides remaining within the photographic emulsions. Despite the ubiquitous presence of ice and snow, water was not readily available for polar adventurers and was only obtained by melting snow, and evidence of a lack of water for this necessary darkroom work would support the theory of Jackson's photo-printing in the Arctic [40]. Any residual halides within the photographs would also pose a risk to any potential use or display, as prints would still be light-sensitive and continue to print out and darken with sustained light exposure. However, the type of cameras used during the expedition further supports a hypothesis that the preliminary prints were made in the Arctic. In contact printing, the sensitized paper and photographic negative are in direct contact with each other, resulting in a print with the same size as the original negative. According to Jackson's account, two cameras were used during the expedition: a larger half plate stand camera and a Frena No. 2, a significantly smaller and more portable hand camera [41]. The Frena was introduced in 1893 by UK manufacturer R. \& J. Beck Ltd. Containing a pack of multiple individual celluloid sheet films and an internal mechanism that allowed for the celluloid sheets to be exposed individually, the Frena was the latest innovation in 1890s photographic technology [42]. The negative size of Frena No. 2 was $3.25 \times 4.25$ inches, corresponding to approximately $8.2 \times 10.7 \mathrm{~cm}$ [43]. These dimensions are similar to those of the preliminary photographs investigated here, whose somewhat smaller sizes may be explained by the fact that the later prints were likely trimmed to the size of $6.8-7 \times 9.4-10.1 \mathrm{~cm}$. Industrially produced photographic materials have long been standardized, and the slight variation in print size informs the viewer that something outside of that process caused the variation. With a photographic paper the same or similar in size to the Frena negative, a contact print could be made and the edges-which may have featured the edge of the negative or contact printing frame-then trimmed, a typical finishing step.
Analysis of the photographs with pXRF spectroscopy did not reveal any elements in quantities that might suggest incomplete processing. According to Jackson's accounts, he used both silver chloride sensitized printing-out papers and silver chloride/silver chlorobromide gaslight papers, both of which were commercially obtainable [40]. However, only weak peaks of halogens-mostly chlorine $(\mathrm{Cl})$-were detected in XRF spectra (Additional file 1: Table S1), although partially masked by the interference with the Rh $\mathrm{L}$ lines. This result indicates that the photographs are properly fixed, and that there is little danger of the images continuing to print out and darken upon light exposure [27]. Intense peaks attributed to barium $(\mathrm{Ba})$ were identified in the majority of photographs examined, along with strontium $(\mathrm{Sr})$ and sulfur $(\mathrm{S})$ (Fig. 2). These elements are all indicative of the presence of a baryta layer over the paper and beneath the photosensitive emulsion in silver-gelatin prints. The baryta layer, typically composed of a mixture of barite $\left(\mathrm{BaSO}_{4}\right)$, strontium sulfate $\left(\mathrm{SrSO}_{4}\right)$, titanium dioxide $\left(\mathrm{TiO}_{2}\right)$, and gelatin [44], provides an opaque white surface to the photographic paper, enabling the printing of a more sharply detailed image. Examination with handheld Raman spectroscopy further confirmed the presence of barite in most prints, exhibiting bands at 457, 616, 642, and $988 \mathrm{~cm}^{-1}$. The baryta layer is not present in three of the improved photographs under investigation (171, 172, and 173), as shown by combined visual observation, pXRF, and Raman analysis. It is worth noting that, if not properly completed, washing, the final step of photographic processing, may leave residual sulfur from the thiosulphate compounds used for fixing developed prints [23], slowly causing the discoloration of the photographs. Accordingly, the finding of this element in the XRF spectra would imply an inappropriate washing time. However, in the photographs analyzed, the detection of $\mathrm{S}$ is also due to the presence of barite and, thus, the hypothesis of inappropriate washing cannot be confirmed.

Notably, pXRF could not identify any silver (Ag) even when increasing collection times and current, although the photographs were undoubtedly printed on silver-gelatin paper. In particular, the $\mathrm{Ag} \mathrm{K \alpha}$ line was not detected in any of the spectra acquired from the preliminary photographs, while the presence of argon (Ar) from the air surrounding the analyzed spot prevented identification of the $\mathrm{Ag} \mathrm{L}$ lines. Only in a few cases, a very weak signal arising at $3.3 \mathrm{keV}$ could be assigned to $\mathrm{Ag}$, corresponding to its $\mathrm{L} \beta 2$ line (Fig. 2). On the other hand, Ag peaks of very low intensity were detected on the improved positives (Fig. 3). Instrumental limitations of pXRF might hinder a straightforward detection of Ag, which would be more efficiently identified by using a helium gas flux, currently not available in our portable instrumentation, 

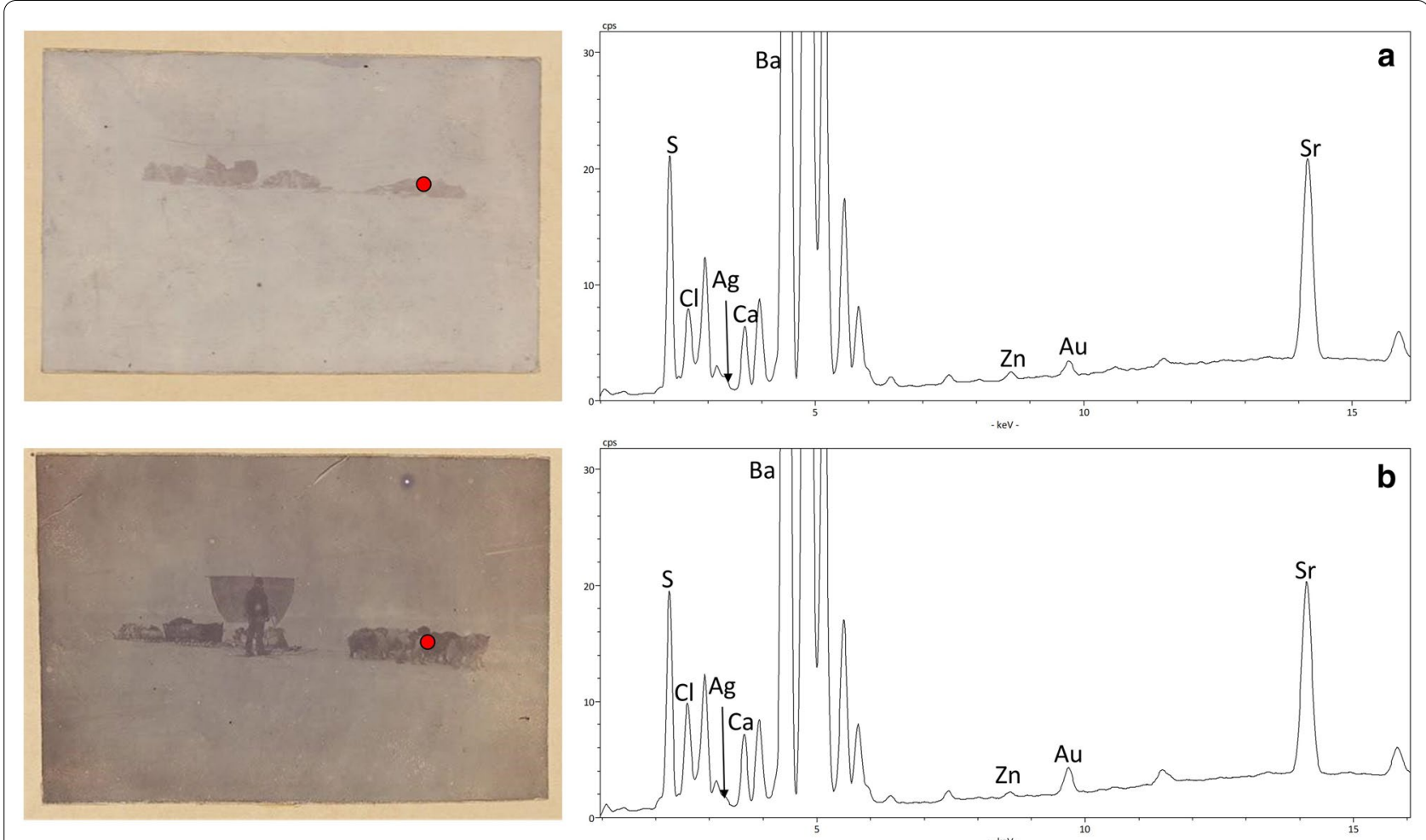

Fig. 2 XRF spectra acquired from dark gray areas of a plate 93 and $\mathbf{b}$ plate 97 (preliminary photographs), expected to yield a more intense Ag signal. Both spectra show a very weak peak at energies corresponding to the Ag L $\beta 2$ line, as well as Au peaks indicating that these photographs were gold-toned. Exact locations of the spots examined are marked with red dots

or high-resolution techniques such as low-vacuum SEM/ EDS [45]. However, in the present case, a choice was made in favor of non-invasive analysis to preserve the physical integrity of the photographic prints. Gold $(\mathrm{Au})$ was also present in the majority of the photographs analyzed $(11,18,23,31,39,48,56,93,94,97,108$, and 118)
(Fig. 2), indicating the use of a gold chloride toner. Gold toning-chemically based on electroless gold platingincreases the chemical stability of the Ag image particles by inhibiting the formation of degradation products such as silver sulfides, and changes the image tonality from a reddish-brown to a warm purple. The easier detection
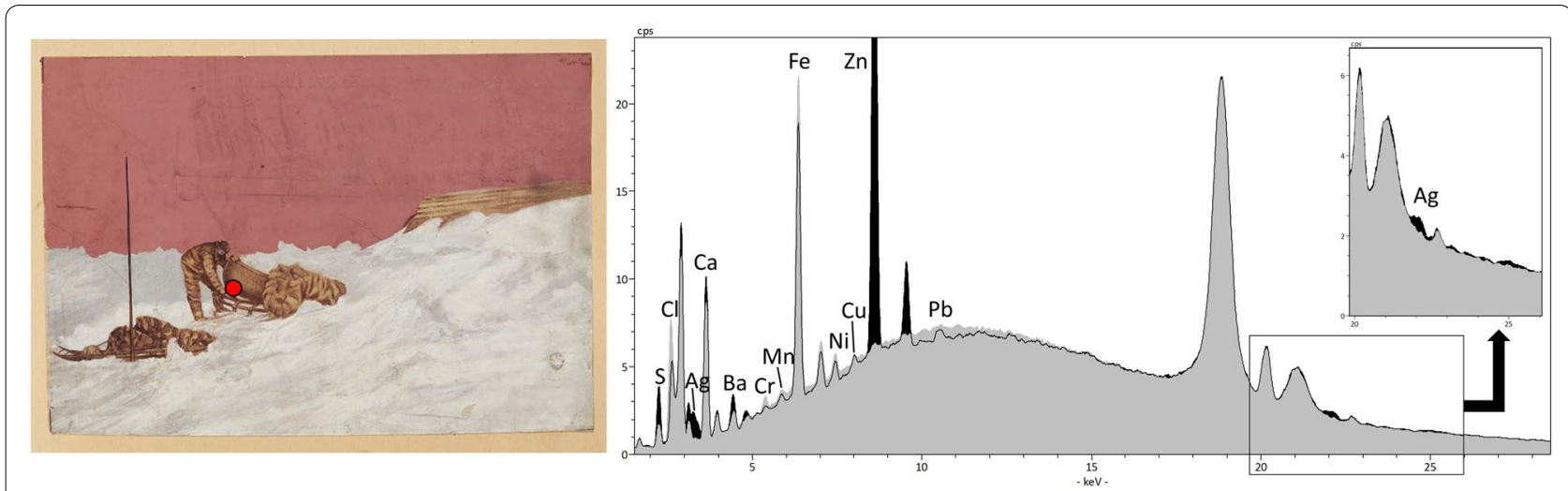

Fig. 3 XRF spectrum acquired from a gray area (black pattern) of plate 171 (improved positive), compared with a reference spectrum collected from the photographic paper (gray pattern). A weak peak of Ag is clearly detected in the blow-up rectangle. The exact location of the spot examined is marked with a red dot 
of the gold toning compared to the colloidal silver image material upon XRF analysis may be explained by considering that the process of gold toning both plates the $\mathrm{Ag}$ particles with $\mathrm{Au}$ and replaces atoms of $\mathrm{Ag}$ in those particles with atoms of $\mathrm{Au}$, prompting the formation of silver chloride [23, 46]. As a result, the gold toning, even when applied as an incomplete coating, would obscure the internal $\mathrm{Ag}$ core of the image particles from the XRF beam, acting as a shield and thus inducing a significantly weaker response from $\mathrm{Ag}$ itself [Nishimura 2019, personal communication]. The presence of $\mathrm{Au}$ is significant as it indicates that, if these photographs were indeed printed in the Arctic, Jackson and his expedition were also toning their photographic prints or using self-toning papers, which were manufactured by Eastman Kodak during this time. While gold toning was a standard processing step during the 19th century, it was not required. Although Jackson does discuss photography to an unusual extent in the published account of the expedition, his private journals are significantly more explicit. On September 24th, 1896, he writes: "I printed from negatives all day and toned and fixed them in the evening [..." [41]. This journal entry, and many others, suggest that any photograph production in Franz Josef Land was carried out professionally. Gold toning requires an extra waterbased bath during print processing, using a significant amount of the expedition's relatively scarce water supply for photographic rather than consumptive purposes. Adhering to the standard best practice photographic processing method, even in a challenging climate, implies that obtaining and bringing back high-quality imagery were essential requirements, as legible photographs contributed to the veracity of the expedition's scientific discoveries and daily hardships.

\section{Improved positives: the retouching palette}

Photographic literature of the late 19th and early 20th centuries that deals with retouching is primarily concerned with coloring a positive print or retouching the negative itself, rather than with the creation of improved positives. In understanding these texts, however, the distinction between a colored positive print intended as a final object and an improved positive, a temporarily object that is retouched only to be rephotographed to create a better quality negative, must be made. With this distinction in mind, several texts provide suggestions for specific colors and appropriate suppliers, indicating that the Arctic Exploration album photographs may have been overpainted with white in the form of zinc oxide, ivory black, a blue like indigo or cobalt blue, red iron oxides, red lakes such as madder or carmine lakes, as well as sepia or neutral tint [31, 47-49]. James Newman's 1874 volume also recommends the use of "body colors" in retouching both positives and negatives. "Body color" is another term for gouache, a type of matte watercolor based on opaque pigments, often containing chalk or other white fillers [50].

The limited color palette found on photographs in the Arctic Exploration album includes white, gray, black, blue, red, pink, and purple tones. The paints appear very matte and opaque, leanly bound, and heavily applied with a brush, though the areas of detail are finely executed. These physical characteristics, along with the water solubility of the binders, suggest the use of gouache. Transmission FTIR analysis of four microscopic samples ubiquitously detected protein and polysaccharide (Fig. 4), characterized by series of most distinctive bands at 1646 and $1541 \mathrm{~cm}^{-1}$ (amide I and II), and 1152, 1082, and $1027 \mathrm{~cm}^{-1}$, respectively. The protein component might point to the use of a gelatin photographic emulsion, while the polysaccharide is probably present as binder for the gouache. Similarly to watercolor, gouache often contains a gum Arabic binder [51], although materials such as starch were also employed [52]. Dextrin, a water-soluble polysaccharide produced by the hydrolysis of starch, has been used as a binder for poster and cheap tempera paints [53]. FTIR spectra also displayed bands of inorganic components, such as barite (sample S1) at $1182,1112,1075,985$, and $637 \mathrm{~cm}^{-1}$, and calcite (samples S3 and S4) at 2516, 1795, 1418, 875 , and $714 \mathrm{~cm}^{-1}$. This

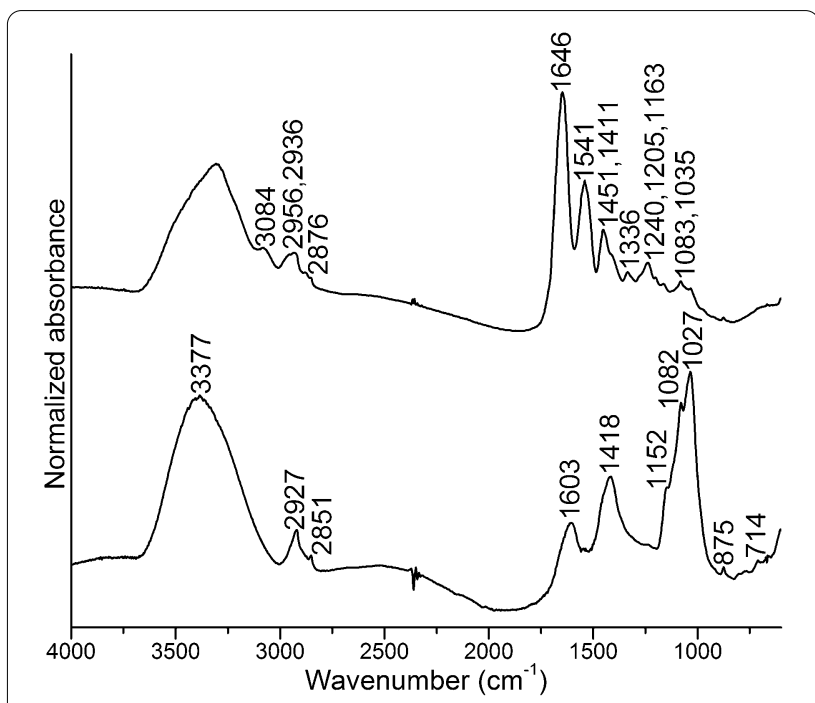

Fig. 4 FTIR spectra acquired from sample S3, i.e. a scraping of purple paint from the sky of plate 48 (improved positive). Materials identified in the spectra include calcite $\left(1418,875,714 \mathrm{~cm}^{-1}\right)$, protein $(3084$, $2956,2936,2876,1646,1541,1451,1411,1336,1240,1205,1163$, $\left.1083,1035 \mathrm{~cm}^{-1}\right)$, and polysaccharide $(3377,2927,2851,1603,1418$, $1152,1082,1027 \mathrm{~cm}^{-1}$ ) 
finding is likely related to the use of these materials as fillers, further supporting the hypothesis of gouache.

To the untrained eye, the level of retouching on the photographs examined in this study is surprising; some of them are so extensively modified that, at first glance, they are barely recognizable as photographs. The most visually striking areas of retouching in the album are the red and pink skies painted onto several photographs $(23,108,118,171,172$, and 173), which increased tonal contrast and visual interest in darker gray area and night skies: red functioned as masking because of the light sensitivity, or lack thereof, of late 19th-century photographic emulsions, which were orthochromatic. The sensitivity of the silver halides extended only into the green/yellow wavelengths and not into the orange/red portion of the electromagnetic spectrum. As a result, reds appeared as black and pinks created grays, which the retouchers knew and used to their advantage. During the retouching process, the skies were masked out, while highlights were lifted and details intensified. The tonalities of reds and pinks, combined with the colors recommended by 19th-century manuals, suggested possible mixtures of Indian red (iron oxide) and Chinese white (zinc oxide) [31]. When examined under long-wave UV illumination, areas of white retouching invariably display a bright yellow fluorescence (Fig. 5a, b) - the same also exhibited by reds and pinks, though to a lesser degree (Fig. 5c, d). As the colors are matte, the greatest contribution to the observed fluorescence is more likely due to a pigment rather than to a binder. Zinc oxide, a white pigment commonly used for watercolors, fluoresces yellow under UV light [52]. The presence of zinc oxide would account for the difference between the fluorescence emission in the white areas, presumably made with pure zinc oxide, as opposed to the red and pink skies, where this material would be mixed with other pigments to achieve the desired nuance.

Ten prints were selected for investigation of the retouching palette, with scientific analysis of multiple areas representing various shades of the above-mentioned colors. White paints analyzed on several locations with pXRF were found to contain mainly zinc $(\mathrm{Zn})$, indicative of the use of zinc white, which confirms the interpretation of the long-wave UV light images. In addition to Zn, XRF spectra display several other elements that, as discussed above, are attributed to the photograph processing (e.g. $\mathrm{Cl}$ and, sometimes, $\mathrm{Au}$ ) and to the presence of a baryta layer (e.g. Ba, Sr, and S). The identification of zinc white was further confirmed by Raman spectra collected with both the handheld and benchtop spectrometers, all showing the main band of this material at $437 \mathrm{~cm}^{-1}$. The group of red paints includes different
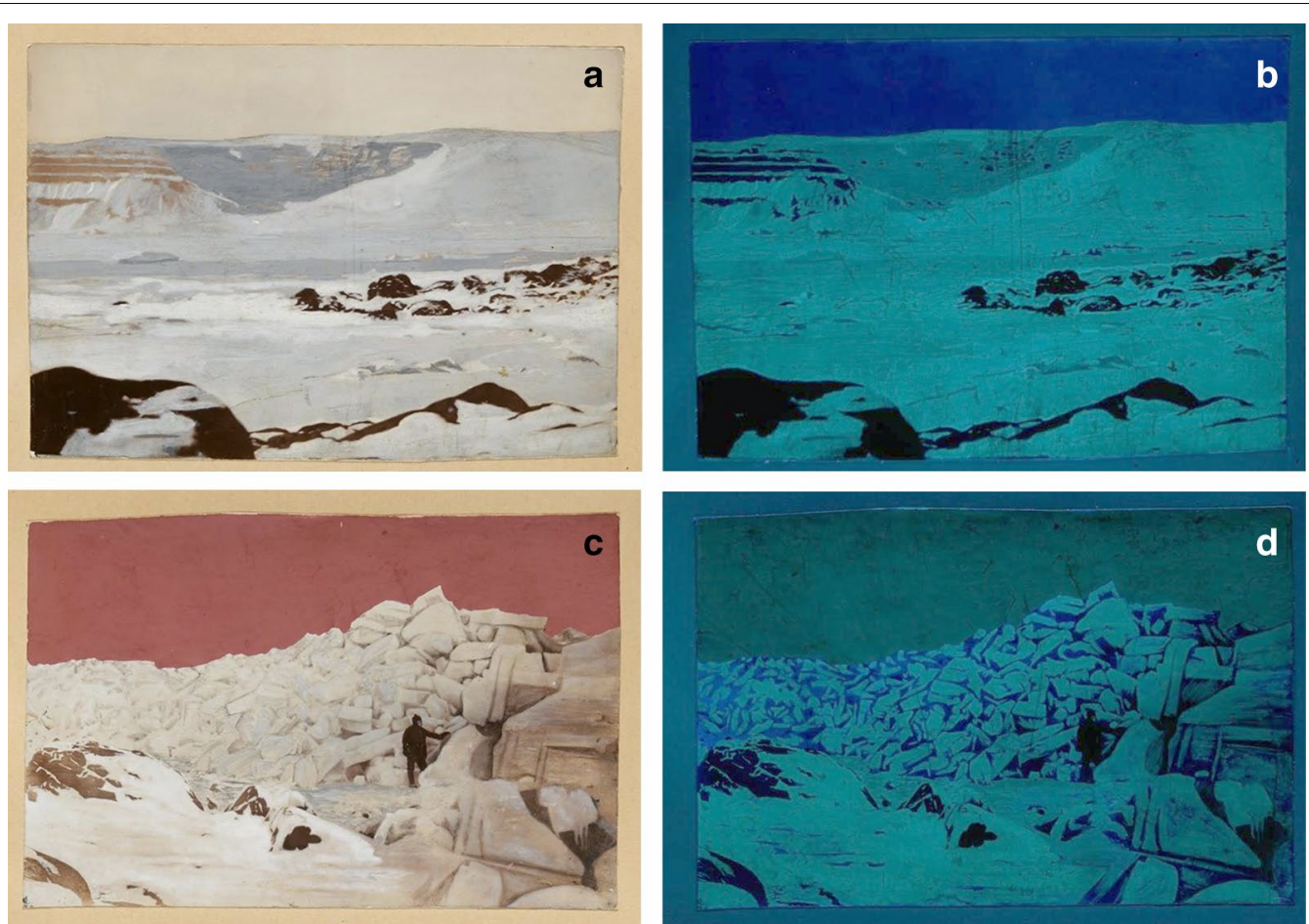

Fig. 5 Normal light (left) and UV light (right) photographs of $\mathbf{a}$, b plate 11 and $\mathbf{c}$, d plate 23 (improved positives). The intense yellow fluorescence detected in areas retouched with white overpaint suggests the use of a zinc oxide pigment 
shades, obtained as mixtures of white and red pigments in variable proportions. X-ray lines of iron $(\mathrm{Fe})$ and $\mathrm{Zn}$, the latter indicative of the use of zinc white, were identified in all the red hues. The observation of an inflection point at $580 \mathrm{~nm}$ and an apparent absorbance maximum at $850 \mathrm{~nm}$ in FORS spectra indicates that Fe is present in the form of iron(III) oxide (Fig. 6a). The use of iron-containing red earths was further corroborated by the detection of Raman bands at 224, 290, 408, 494, and $608 \mathrm{~cm}^{-1}$ (Fig. 6b).

Based on the information reported in technical manuals from the time period [31, 47, 48], blue areas were expected to be tinted with indigo, but none of the techniques employed in this study detected indigotin in any of the bluish tones analyzed. In those locations, however, non-invasive analysis with handheld Raman spectroscopy identified a carbon-based black, characterized by two broad bands at $\sim 1330$ and $\sim 1595 \mathrm{~cm}^{-1}$ (Fig. 7b). Microscopic examination of sample S1, removed from the snowbanks on photograph 18 , revealed that the bluelooking paint in this area was actually obtained as a mixture of black and white pigments. Analysis of this sample by micro-Raman spectroscopy confirmed the presence of a carbon-based black with zinc white. In addition, BSE images revealed the presence of sparse particles of less than $5-\mu \mathrm{m}$ in size and mainly composed of calcium (Ca) and phosphorus $(\mathrm{P})$, enabling to further specify the identity of the black pigment as bone or ivory black (Fig. 7c, d).

Purple retouching, including passages of a purplebluish hue, gave rise to the typical Raman bands of carbon-based black pigments when analyzed non-invasively with a handheld system, while FORS of the darkest tones detected the distinctive spectral features of iron(III) oxide. Sampling, in this case, was key to unravel the complex nature of this range of colors. Samples S2, S3, and S4, respectively removed from the skies of photographs 31,48 , and 56, appeared, under magnification, as an abundance of black particles distributed on the surface of a pink paint displaying minute spots of more intense red color (Fig. 8). Raman spectra collected from individual black and pink particles showed that these samples are all based on combinations of a carbon-based black pigment, iron(III) oxide, and zinc white. As in the case of black retouching paint, analysis with SEM/EDS of the carbonbased pigment detected primarily $\mathrm{Ca}$ and $\mathrm{P}$, confirming that it consists, more precisely, of bone or ivory black. The elemental maps produced by EDS also highlight a ubiquitous distribution of $\mathrm{Zn}$ in the samples examined, in which iron-rich particles are scattered in various proportions (Fig. 9). The frequent association of such ironrich particles-likely iron oxides or hydroxides-with aluminum (Al)- and silicon $(\mathrm{Si})$-containing compounds is indicative of the presence of aluminosilicate minerals such as micas and quartz, typical of natural materials. Based on this data, the use of natural red earths may be tentatively hypothesized.

As expected and based on results from other colors, areas of gray and black retouching, analyzed only with handheld techniques, were found to consist of mixtures of zinc white and carbon-based black, combined in various proportions to obtain different hues.

Although the improved positives exhibit a highly limited palette of affordable materials such as earth
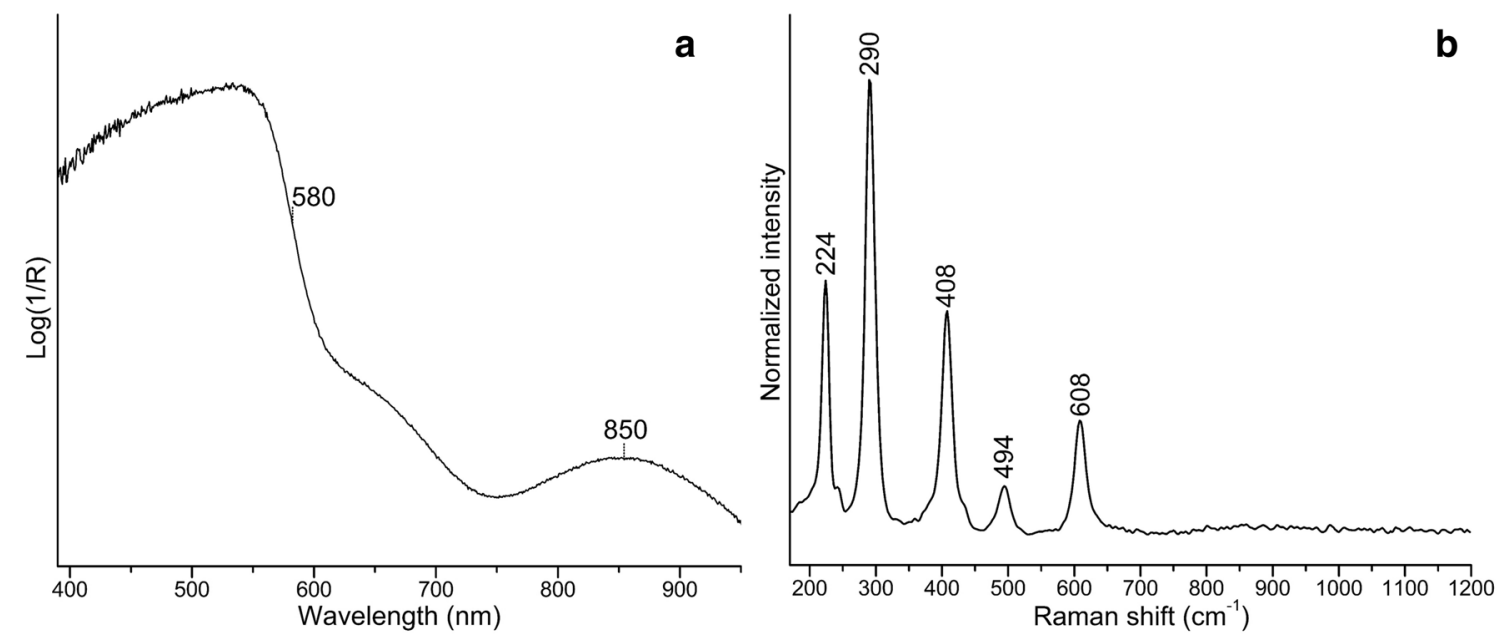

Fig. 6 a FORS spectrum acquired from a pink area of plate 23 (improved positive), where an inflection point at $580 \mathrm{~nm}$ and an apparent absorbance maximum at $850 \mathrm{~nm}$ indicate the presence of iron(III) oxide. b Raman spectrum collected from a pink area of the same photograph, where peaks at 224, 290, 408, 494, and $608 \mathrm{~cm}^{-1}$ are attributed to iron(III) oxide 

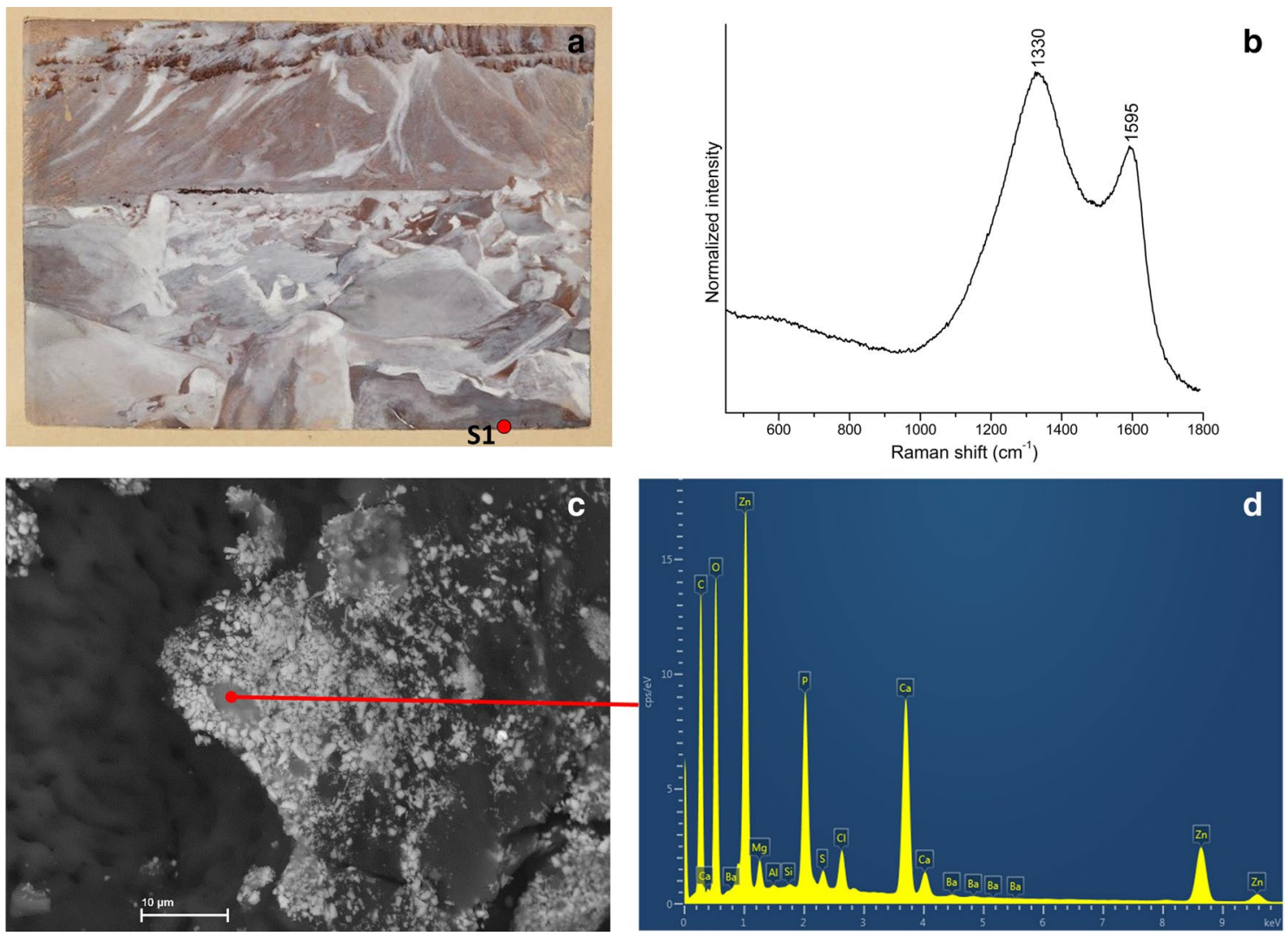

Fig. 7 a Normal light photograph of plate 18 (improved positive), with indication of sampling site. b Raman spectrum acquired from sample S1, i.e. a scraping of blue paint from the snowbanks, where two broad bands around 1330 and $1595 \mathrm{~cm}^{-1}$ indicate the presence of a carbon-based black. $\mathbf{c}$ BSE image of a portion of sample S1. d EDS spectrum collected from a particle in sample S1, in which the relatively high content of calcium (Ca) and phosphorus (P) enabled to further specify the identity of the carbon-based black pigment as bone or ivory black


Fig. 8 a Normal light photograph of plate 31 (improved positive), with indication of sampling site. b Photomicrograph of sample S2, i.e. a scraping of purple-blue paint from the sky, taken in reflected light using fiber optics illumination under a stereomicroscope

pigments, carbon black, and starch binders, the details of the retouching are applied with care and delicacy. Arctic explorers such as Jackson were not the only individuals to invest significant amounts of time and effort into their production of photographs: remarkable skill went into 

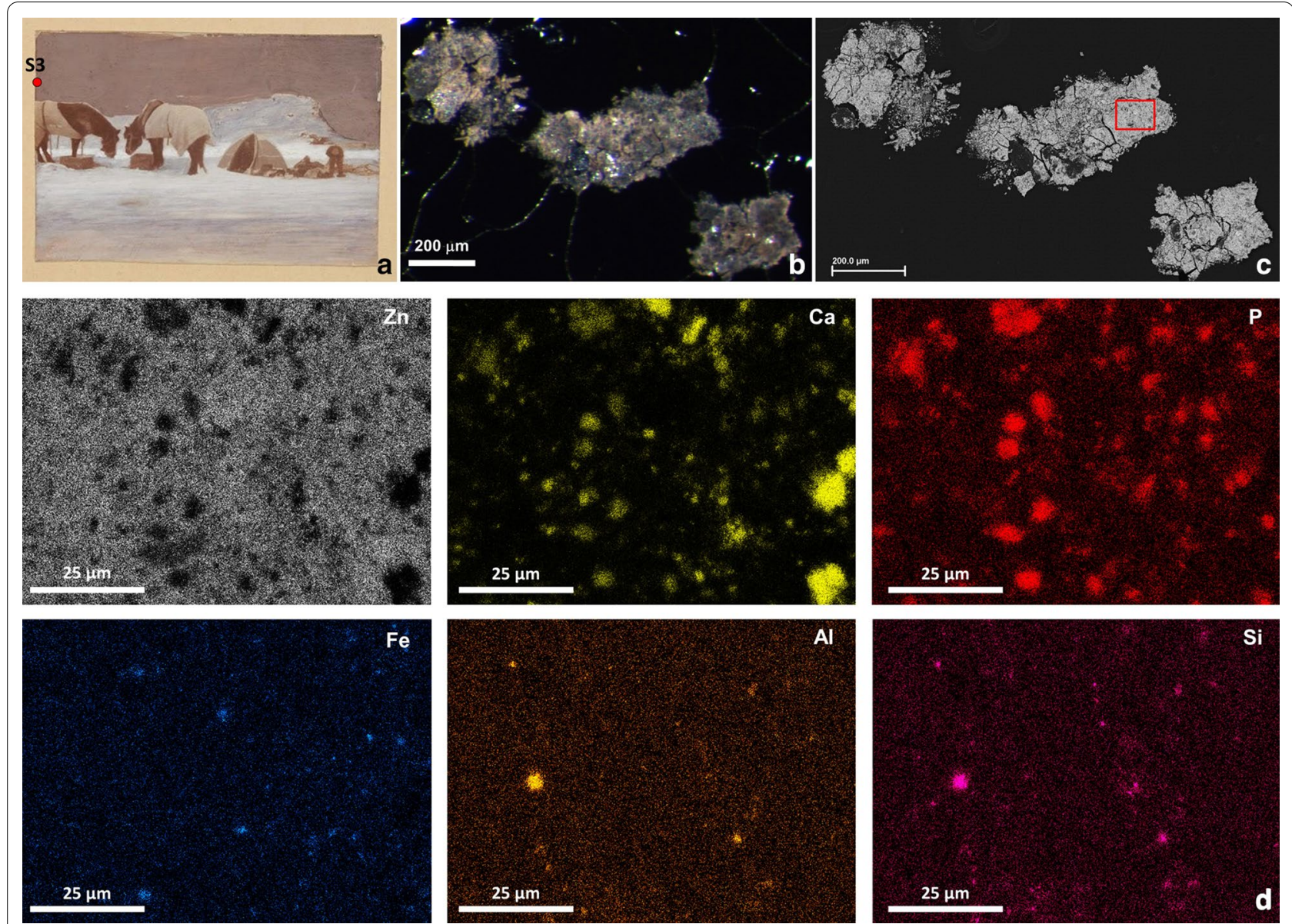

Fig. 9 a Normal light photograph of plate 48 (improved positive), with indication of sampling site. b Photomicrograph of sample S3, i.e. a scraping of purple paint from the sky, taken in reflected light using fiber optics illumination under a stereomicroscope. c BSE image of sample S3, with indication of the area mapped with EDS. $\mathbf{d}$ X-ray elemental maps of zinc (Zn), calcium (Ca), phosphorus (P), iron (Fe), aluminum (Al), and silicon (Si) collected from a portion of sample S3

perfecting these "improved positives" even if they did not use the highest quality or most expensive colors available.

\section{Conclusions}

The present study focused on a selection of sixteen photographs, all documenting the Jackson-Harmsworth expedition to Franz Josef Land between 1894 and 1897, contained in an album titled Arctic Exploration in the Photography Collection of the NYPL. Visual examination of the photographs combined with scientific analysis by means of an array of non-invasive and micro-invasive spectroscopic techniques sought to determine whether any of these photographs may have been printed on site, during the expedition in the Arctic, as well as to investigate the photographic process and materials used for retouching improved positives. While no evidence of residual silver halides from improper processing was found, interesting details and technical aspects of photographically illustrated books during the late 19th and early 20th century were uncovered. Identifying the use of gold toning as part of the photographic processing-a standard step at the time, yet not required for successful imagemaking-attests to Jackson's serious and professional approach to photography. Similarly, the retouching of the photographs was handled with great care, so that the book would contain high-quality halftone reproductions. The color palette consists of a limited range of gouache colors including zinc white, red iron earths, and bone or ivory black. These materials are consistent with those reported in late 19th-century photographic technical manuals, many of which are held in the research collection of the NYPL's Wallach Division of Art, Prints and Photographs. The relatively low quality of the retouching materials utilized-starch and not gum Arabic, and common earth pigments rather than expensive organic colorants-supports the view that the improved positives were valued for their ability to 
translate an experience and that survival of the collection is unusual. These objects were transitional, occupying an intermediate phase between negative and photomechanical reproduction, and, as such, they were not typically regarded as worth keeping. The analysis of the Arctic Exploration album contributes to the understanding of photography as a tool of exploration, in both documenting adventures and disseminating them to the public. Undoubtedly, this research increases knowledge of the technical aspects of photographically illustrated books during the late 19th and early 20th centuries and allows for a comparison between materials used for retouching improved positives with those described in contemporary texts.

\section{Abbreviations}

pXRF: Portable X-ray fluorescence spectroscopy; FORS: Fiber optics reflectance spectroscopy; FTIR: Fourier-transform infrared spectroscopy; SEM/EDS: Scanning electron microscopy with energy-dispersive X-ray spectroscopy; BSE: Back-scattered electron.

\section{Supplementary Information}

The online version contains supplementary material available at https://doi. org/10.1186/s40494-021-00506-3.

Additional file 1: Table S1. Results of XRF analysis expressed as count per second (cps) of the main elements detected in the photographs. Instrument settings for each analysis have been reported in the last column (n.d. $=$ not determined).

\section{Acknowledgements}

The authors would like to acknowledge the University of Cambridge's Scott Polar Research Institute, especially Laura Ibbett and Naomi Boneham at the Library and Archives and Lucy Martin at the Picture Library, for their assistance with the papers of Frederick George Jackson.

\section{Authors' contributions}

EB and FP performed in-situ PXRF, Raman, and FORS analysis, and interpreted results. EB carried out SEM/EDS analysis and data interpretation, and drafted the manuscript with inputs from all other authors. FP removed samples, conducted Raman and FTIR analysis and data interpretation, and revised the manuscript. JK examined and treated the photographic album, researched the technical history of Arctic photography and of retouching photographic negatives and positives, and studied the expedition journals of Frederick George Jackson. EC researched the history of Arctic photography. All authors read and approved the final manuscript.

\section{Funding}

This research was made possible by the Network Initiative for Conservation Science (NICS), a Metropolitan Museum of Art program. Support for NICS was provided by a grant (31500630) from The Andrew W. Mellon Foundation.

\section{Availability of data and materials}

All data generated during this study are either included in this published article or available from the corresponding author upon reasonable request.

\section{Declarations}

\section{Competing interests}

The authors declare that they have no competing interests.

\section{Author details}

${ }^{1}$ Department of Scientific Research, The Metropolitan Museum of Art, 1000 Fifth Avenue, New York, NY 10028, USA. ${ }^{2}$ Goldsmith Conservation Laboratory, The New York Public Library, Library Service Center, 31-11 Thomson Avenue, Long Island City, NY 11101, USA. ${ }^{3}$ Steel City Art Conservation, 803 North Avenue, Pittsburgh, PA 15209, USA. ${ }^{4}$ Wallach Division of Art, Prints and Photographs, The New York Public Library, 476 Fifth Avenue, New York, NY 10018, USA.

Received: 17 December 2020 Accepted: 8 March 2021

Published online: 19 March 2021

\section{References}

1. Ryan JR. Photography and exploration. London: Reaktion Books; 2013.

2. Wamsley DW. Polar Hayes: the life and contributions of Isaac Israel Hayes. Philadelphia: American Philosophical Society; 2009.

3. Condon RG. The history and development of Arctic photography. Arctic Anthropol. 1989;26:46-87.

4. Kugler RC. William Bradford: sailing ships and Arctic Seas. Seattle: University of Washington; 2003.

5. Daffner L, Kushel D, Messinger JM. Investigation of a surface tarnish found on 19th-century daguerreotypes. J Am Inst Conserv. 1996;35(1):9-21.

6. Anglos D, Melesanaki K, Zafiropulos V, Gresalfi MJ, Miller JC. Laser-induced breakdown spectroscopy for the analysis of 150-year-old daguerreotypes. Appl Spectrosc. 2002;56(4):423-32.

7. Gregory EA, DeRoo CS, Mansfield JF. Characterization and restoration of 19th century daguerreotypes by SEM, XEDS, and FIB. Microsc Microanal. 2007;13(S02):1422. https://doi.org/10.1017/S1431927607079627.

8. Centeno SA, Meller T, Kennedy N, Wypyski M. The daguerreotype surface as a SERS substrate: characterization of image deterioration in plates from the 19th century studio of Southworth \& Hawes. J Raman Spectrosc. 2008;39(7):914-21.

9. Centeno SA, Schulte F, Kennedy NW, Schrott AG. The formation of chlorine-induced alterations in daguerreotype image particles: a high resolution SEM-EDS study. Appl Phys A Mater. 2011;105(1):55.

10. Vicenzi EP, Landin T, Herzing AA. Examination of a 19th century daguerreotype photograph using high resolution scanning transmission electron microscopy for 2D and 3D nanoscale imaging and analysis. Microsc Microanal. 2014;20(S3):2000-1.

11. Marquis EA, Chen Y, Kohanek J, Dong Y, Centeno SA. Exposing the subsurface of historical daguerreotypes and the effects of sulfur-induced corrosion. Corros Sci. 2015;94:438-44.

12. Davis JM, Vicenzi EP. Optimizing compositional images of daguerreotype photographs using post processing methods. Herit Sci. 2016;4(14):1-8. https://doi.org/10.1186/s40494-016-0080-7.

13. Ravines P, Li L, McElroy R. An electron microscopy study of the image making process of the daguerreotype, the 19th century's first commercially viable photographic process. J Imaging Sci Technol. 2016;60(3):30504-1.

14. Grieten E, Schalm O, Tack P, Bauters S, Storme P, Gauquelin N, Caen J, Patelli A, Vincze L, Schryvers D. Reclaiming the image of daguerreotypes: characterization of the corroded surface before and after atmospheric plasma treatment. J Cult Herit. 2017;28:56-64.

15. Kozachuk MS, Sham TK, Martin RR, Nelson AJ, Coulthard I, McElhone JP. Recovery of degraded-beyond-recognition 19th century daguerreotypes with rapid high dynamic range elemental $X$-ray fluorescence imaging of mercury L emission. Sci Rep. 2018;8(9565):1-10. https://doi.org/10.1038/ s41598-018-27714-5.

16. Kozachuk MS, Sham TK, Martin RR, Nelson AJ, Coulthard I. Exploring tarnished daguerreotypes with synchrotron light: XRF and $\mu$-XANES analysis. Herit Sci. 2018;6(1):12. https://doi.org/10.1186/s40494-018-0171-8.

17. Kozachuk MS, Avilés MO, Martin RR, Potts B, Sham TK, Lagugné-Labarthet F. Imaging the surface of a hand-colored 19th century daguerreotype. Appl Spectrosc. 2018;72(8):1215-24.

18. Kozachuk MS, Sham TK, Martin RR, Nelson AJ, Coulthard I. Eyeing the past: synchrotron $\mu$-XANES and XRF imaging of tarnish distribution on 19th century daguerreotypes. J Synchrotron Radiat. 2019;26(5):1679-86. 
19. Ravines $P$, Nazarenko AY. Characterizing the image forming particles of modern ungilded daguerreotypes using XRD and SEM. Microsc Microanal. 2019;25(4):1037-51.

20. Schlather AE, Gieri P, Robinson M, Centeno SA, Manjavacas A. Nineteenthcentury nanotechnology: the plasmonic properties of daguerreotypes. Proc Natl Acad Sci. 2019;116(28):13791-8.

21. Eremin K, Tate J, Morrison-Low A, Berry J, Stevenson S. Non-destructive analysis of nineteenth century Scottish calotype negatives and salt prints. In: MRS Online proceedings library archive. 2002;712:I110.2.1-10.

22. Moore C. An analytical study of EuGene Atget's photographs at the Museum of Modern Art. Top Photogr Preserv. 2007;12:194-210.

23. Cattaneo B, Chelazzi D, Giorgi R, Serena T, Merlo C, Baglioni P. Physicochemical characterization and conservation issues of photographs dated between 1890 and 1910. J Cult Herit. 2008;9(3):277-84.

24. Freeman SK. A technical study on the work of Felice Beato in Asia. Top Photogr Preserv. 2011;14:59-69.

25. Sessa C, Barro L, Centeno SA, Bagán H, Carò F, García JF. Investigation of the possible origins of sulfur in 19th century salted paper photographs by X-ray fluorescence spectroscopy. X-Ray Spectrom. 2016;45(3):176-84.

26. Modica A, Alberghina MF, Brai M, Bruno M, Di Bella M, Fontana D, Tranchina L. XRF analysis to identify historical photographic processes: the case of some Interguglielmi Jr's images from the Palermo Municipal Archive. Radiat Phys Chem. 2017;135:76-80.

27. Barro L, Sanderson K, Centeno SA, Saunders B. The exhibition and characterization of seven salted paper prints. J Am Inst Conserv. 2020;59:1-5.

28. McClelland A, Bulat E, Bernier B, Murphy EL, Specular Reflection FTIR. A non-contact method for analyzing coatings on photographs and other cultural materials. J Am Inst Conserv. 2020;59(2):123-36.

29. Szulc J, Ruman T, Karbowska-Berent J, Kozielec T, Gutarowska B. Analyses of microorganisms and metabolites diversity on historic photographs using innovative methods. J Cult Herit. 2020:45:101-13.

30. Rampazzi L, Brunello V, Campione FP, Corti C, Geminiani L, Recchia S, Luraschi M. Non-invasive identification of pigments in Japanese coloured photographs. Microchem J. 2020;12:105017.

31. Newman J. The principles and practice of harmonious colouring, in oil, water, and photographic colours, especially as applied to photographs on paper, glass, and canvas by an artist photographer. With a supplementary chapter on varnishing and retouching negatives. 10th ed. London: Piper and Carter; 1874.

32. Aceto M, Agostino A, Fenoglio G, Idone A, Gulmini M, Picollo M, Ricciardi P, Delaney JK. Characterisation of colourants on illuminated manuscripts by portable fibre optic UV-visible-NIR reflectance spectrophotometry. Anal Methods. 2014;6(5):1488-500.

33. Pozzi F, Basso E, Rizzo A, Cesaratto A, Tague TJ Jr. Evaluation and optimization of the potential of a handheld Raman spectrometer: in situ, noninvasive materials characterization in artworks. J Raman Spectrosc. 2019;50(6):861-72.

34. Cronin E, Keister J. Polar expeditions: a photographic landscape of sameness? In: White D, Goldie C, editors. Proximity and distance in northern landscape photography: contemporary criticism, curation and practice, vol. 171. Bielefeld: Transcript; 2020. p. 35-55.

35. Kersting R. Photography in the Far North. In: Kersting R, editor. The white world: life and adventures within the Arctic circle portrayed by famous living explorers. New York: Lewis, Scribner \& Co; 1902. p. 237-8.
36. Dunmore JL. The camera among the icebergs. Phila Photogr. $1869 ; 6: 412-4$

37. Hackleman CW. Commercial engraving and printing: a manual of practical instruction and reference covering commercial illustrating and printing by all processes, for advertising managers. In: Printers, engravers, lithographers, paper men, photographers, commercial artists, salesmen, instructors, students and all others interested in these and allied trades. Indianapolis: Commercial Engraving Publishing Company; 1921. p. 75.

38. Benson R. The printed picture. New York: Museum of Modern Art; 2008.

39. Jackson FG. MS 287/1/1, Frederick Jackson collection. University of Cambridge: Scott Polar Research Institute; 1895.

40. Jackson FG. A thousand days in the Arctic. New York: Harper; 1899.

41. Jackson FG. MS 287/1/2, Frederick Jackson collection. University of Cambridge: Scott Polar Research Institute; 1896.

42. Coe B. Cameras: from daguerreotypes to instant pictures. London: Marshall Cavendish; 1978.

43. Beck R. \& Ltd. The Frena handbook: No. 2 quarter plate size. London: R \& J Beck Ltd.; 1898.

44. Flores-Camacho JM, Nieto-Villena A, Martínez JR, de la Cruz-Mendoza JA, Ortega-Zarzosa G, Solbes-García Á, Balderas-Navarro RE, Lastras-Martnez A. Determination of the layered structure of baryta based heritage photographs by infrared ellipsometry. J Cult Herit. 2019;36:174-82.

45. Peres M, Costa FM, Gomes A, Jardim ME, Ferreira T, Mirão LD, Carvalho ML. Analytical studies of 19th century photographs by non-destructive techniques. In: Rogerio-Candelera MA, Lazzari M, Cano E, editors. Science and technology for the conservation of cultural heritage. London: CRC Press/Bakema; 2013. p. 205-8.

46. Penichon S. Differences in image tonality produced by different toning protocols for matte collodion photographs. J Am Inst Conserv. 1999;38(2):124-43.

47. Bool AH. The art of photographic painting. Santa Barbara: Rocky Nook; 1887

48. Johnson R. A complete treatise on the art of retouching photographic negatives: and clear directions how to finish and colour photographs. London: Marion; 1898.

49. Ourdan JP. The art of retouching. Charleston: Nabu Press; 1891

50. Ellis MH. The care of prints and drawings. Walnut Creek: AltaMira Press; 1995.

51. Granzotto C, Arslanoglu J, Rolando C, Tokarski C. Plant gum identification in historic artworks. Sci Rep. 2017;7:44538. https://doi.org/10.1038/srep4 4538.

52. Gettens RJ, Stout G. Painting materials: a short encyclopedia. New York: Dover Publications; 1966.

53. Gottsegen MD. The painter's handbook: a complete reference. New York: Watson-Guptill; 2006.

\section{Publisher's note}

Springer Nature remains neutral with regard to jurisdictional claims in published maps and institutional affiliations.

\section{Submit your manuscript to a SpringerOpen ${ }^{\odot}$ journal and benefit from:}

- Convenient online submission

- Rigorous peer review

- Open access: articles freely available online

- High visibility within the field

- Retaining the copyright to your article

Submit your next manuscript at springeropen.com 